\title{
FILSAFAT CINA: LAO TSE YIN-YANG KAITANNYA DENGAN TRI HITA KARANA SEBAGAI SEBUAH PANDANGAN ALTERNATIF MANUSIA TERHADAP PENDIDIKAN ALAM
}

\author{
I Wayan Widiana \\ Prodi Pendidikan Guru Sekolah Dasar, Universitas Pendidikan Ganesha Singaraja, Indonesia \\ E-mail:wayan_widiana@yahoo.co.id
}

\begin{abstract}
Abstrak
Filsafat China adalah salah satu dari filsafat tertua di dunia dan dipercaya menjadi salah satu filsafat dasar dari 3 filsafat dasar yang memengaruhi sejarah perkembangan filsafat dunia. Salah satu ajaran pada jaman Klasik filsafat china adalah "Yin Yang". "Yin Yang" adalah dua prinsip induk dari seluruh kenyataan atau yang secara harfiah artinya positif dan negatif, namun implisit mewakili makna yang sangat mendalam tentang dualisme yang saling bertentangan, namun saling melengkapi dalam menyokong kehidupan dan mekanisme universal, sehingga segala sesuatu dalam kenyataan kita merupakan sintesis harmonis dari derajat "Yin" tertentu dan derajat "Yang" tertentu. Penerapan prinsip keseimbangan Yin Yang pada bangunan arsitektur modern seperti Phaeno Science Center di Wofsburg, Germany dan Hotel Marques de Riscal di Elciego, Spanyol terlihat pada penggunaan material yang saling berlawanan, antara yang solid dengan yang transparant, antara yang tegak dengan miring, antara yang memantulkan cahaya dengan yang menyerap cahaya. Di Bali, ada salah satu filsafat yang tidak jauh dengan filsafat Yin Yang, yaitu filsafat Tri Hita Karana. Salah bagiannya menjelaskan tentang Palemahan, yaitu hubungan yang harmonis antara manusia dengan alam. Ajaran ini sudah muncul sejak kepemerintahan Majapahit. Namun Istilah Tri Hita Karana pertama kali diperkenalkan pada tanggal 11 Nopember 1966, pada waktu diselenggarakan Konferensi Daerah I Badan Perjuangan Umat Hindu Bali bertempat di Perguruan Dwijendra Denpasar.
\end{abstract}

Kata Kunci: Filsafat Cina: Yin-Yang; Tri Hita Karana; Pendidikan Alam

\begin{abstract}
Chinese philosophy is one of the oldest philosophies in the world and is believed to be one of the basic philosophies of the 3 basic philosophies that influenced the historical development of world philosophy. One of the teachings of Classical Chinese philosophy is "Yin Yang". "Yin Yang" is the two main principles of all reality or which literally means positive and negative, but implicitly represents a very profound meaning of conflicting dualism, yet complementary in supporting life and universal mechanisms, so that everything in our reality is harmonious synthesis of a certain degree of "Yin" and a certain degree of "Yang". The application of the Yin Yang balance principle in modern architectural buildings such as the Phaeno Science Center in Wofsburg, Germany and the Marques de Riscal Hotel in Elciego, Spain is seen in the use of opposing materials, between the solid and the transparent, between the upright and tilted, between the reflectors light with which absorbs light. In Bali, there is one philosophy that is not far from the Yin Yang philosophy, namely the philosophy of Tri Hita Karana. One part of it explains about Palemahan, which is a harmonious relationship between humans and nature. This teaching has emerged since the Majapahit government. However, the term Tri Hita Karana was first introduced on November 11, 1966, when the Regional Conference of the Balinese Hindu Struggle was held at the Dwijendra College in Denpasar.
\end{abstract}

Keyword: Chinese philosophy; "Yin-Yang”; "Tri Hita Karana; Natural Science 


\section{Pendahuluan}

Filsafat Cina adalah salah satu dari filsafat tertua di dunia dan dipercaya menjadi salah satu filsafat dasar dari tiga filsafat dasar yang mempengaruhi sejarah perkembangan filsafat dunia, disamping filsafat India dan filsafat Barat. Filsafat Cina sebagaimana filsafat lainnya dipengaruhi oleh kebudayaan yang berkembang dari masa ke masa. Ada tiga tema pokok sepanjang sejarah filsafat Cina, yakni harmoni, toleransi, dan perikemanusiaan. Selalu dicarikan keseimbangan, harmoni, suatu jalan tengah antara dua ekstrem: antara manusia dan sesama, antara manusia dan alam, antara manusia dan surga. Toleransi kelihatan dalam keterbukaan untuk pendapat-pendapat yang sama sekali berbeda dari pendapat-pendapat pribadi, suatu sikap perdamaian yang memungkinkan pluralitas yang luar biasa, juga dalam bidang agama. Kemudian, perikemanusiaan. Pemikiran Cina lebih antroposentris daripada filsafat India dan filsafat Barat. Manusia-lah yang selalu merupakan pusat filsafat Cina. Ketika kebudayaan Yunani masih berpendapat bahwa manusia dan dewa-dewa semua dikuasai oleh suatu nasib buta ("Moira"), dan ketika kebudayaan India masih mengajar bahwa kita di dunia ini tertahan dalam roda reinkarnasi yang terus-menerus, maka di Cina sudah diajarkan bahwa manusia sendiri dapat menentukan nasibnya dan tujuannya.

Filsafat Cina dibagi atas empat periode besar yaitu Jaman Klasik (600-200 S.M.), Jaman Neo-Taoisme dan Buddhisme (200 S.M.-1000 M.), Jaman Neo-Konfusianisme (1000-1900), dan Jaman Modern (setelah 1900). Jaman klasik sendiri terbagi atas Taoisme (ajaran metafisika), Konfusianisme (ajaran etika), Yin-Yang (keharmonisan, keselarasan, dan keseimbangan), Moisme (cinta universal), Ming Chia (sekolah dialektik), Fa Chia (sekolah hukum).

Salah satu ajaran yang terkenal dari filsafat Cina pada Jaman Klasik adalah Prinsip "Yin Yang". Ajaran "Yin Yang" berasal dari filsafat Tionghoa dan metafisika kuno yang menjelaskan setiap benda di alam semesta memiliki polaritas abadi berupa dua kekuatan utama yang selalu berlawanan tapi selalu melengkapi. Dalam filosofi Cina, konsep Yin-Yang biasanya di daerah barat disebut Yin dan Yang. Biasanya digunakan untuk mendeskripsikan sifat kekuatan yang saling berhubungan dan berlawanan di dunia ini dan bagaimana mereka saling membangun satu sama lain. Konsep tersebut didasarkan pada asal muasal dari banyaknya cabang ilmu pengetahuan klasik dah filosofi Cina serta dapat digunakan sebagai pedoman pengobatan Cina dan menjadi prinsip dari seni bela diri yang ada di Cina, sebagai contoh Baguazhang, Taijiquan (Tai Chi), dan qigong (Chi Kung) dan ramalan Ching.

Yin dan Yang saling berlawanan dalam interaksi dengan dunia yang lebih luas dan sebagai bagian dari sistem yang dinamis. Semua hal memiliki kedua aspek tersebut yakni Yin dan Yang, tapi tidak setiap aspek tersebut memiliki perwujudan yang jelas pada objek dan mungkin pasang surut atau mengalir dari waktu ke waktu. Konsep Yin dan Yangsering dilambangkan dengan berbagai bentuk yang bervariasi dari simbol Taijitu, yang mana lebih umum dikenal pada kebudayaan barat.

Ada beberapa persepsi (terutama di barat) yang mengatakan bahwa Yin dan Yang selalu dihubungkan dengan sesuatu yang baik dan jahat. Namun, filsafat Taoist biasanya tidak memperhitungkan sesuatu yang baik atau jahat dan penilaian moral, dalam kaitannya dengan konsep keseimbangan. Konfusianisme (Filosofi dari Dong Zhongshu, c. Abad 2SM) tidak melampirkan dimensi moral dari Yin dan Yang. Tapi dalam istilah modern, istilah ini sebagian besar telah teradaptasi olehfilosofi Budha Taoist.

\section{Metode}

Artikel ini disusun dengan metode study kepustakaan. Artikel disusun dengan menelaah referensi dan sumber-sumber yang terkait dengan tema filsafat Cina: Lao Tse, yaitu Yin-Yang kaitannya dengan Tri Hita Karana sebagai pandangan alternatif manusia terhadap pendidikan alam. Telaah penelitian sejenis juga dilakukan untuk mendapatkan simpulan yang akurat.

\section{Hasil dan Pembahasan}

\section{Perkembangan Awal Filsafat Cina}

Berdasarkan penemuan arkeologis, Cina Kuno itu sudah ada sebelum periode Neolitik (5000 SM) baik di sebelah timur laut dan barat laut. Pada periode tersebut, kehidupan komunitas suku berpusat pada penyembahan dewa-dewa leluhur dan dewa-dewa alam. Yang dikenal pada 
periode ini adalah budaya Yangshao, Dawenko, Liangche, Hungsan, benda-benda yang dikeramatkan dan tempat penyembahan.

Pada masa budaya Lungshan (2600 SM-2100 SM), yakni pada saat Raja Yao dan Shun memerintah, kebudayaan Cina yang berpusat pada pengorbanan yang ditujukan bagi roh-roh alam dan nenek moyang tersebar ke daerah Henan, Shandong dan Hubei. Mereka terintegrasi dalam sebuah keadaan politis yang tersatukan, Xia. Ada juga tentang praktek li (ritual) dalam bentuk penghormatan kepada nenek moyang sejak awal sebagaimana diterangkan dalam Period of Jade.

Tradisi pemikiran filsafat di Cina bermula sekitar abad ke-6 SM pada masa pemerintahan Dinasti Chou di Utara. Kon Fu Tze, Lao Tze, Meng Tze dan Chuang Tze dianggap sebagai peletak dasar dan pengasas filsafat Cina. Pemikiran mereka sangat berpengaruh dan membentuk ciri-ciri khusus yang membedakannya dari filsafat India dan Yunani. Pada masa hidup mereka, negeri Cina dilanda kekacauan yang nyaris tidak pernah berhenti. Pemerintahan Dinasti Chou mengalami perpecahan dan perang berkecamuk di antara raja-raja kecil yang menguasai wilayah yang berbeda-beda. Sebagai akibatnya rakyat sengsara, dihantui kelaparan dan ratusan ribu meninggal dunia disebabkan peperangan dan pemberontakan yang bertubi-tubi melanda negeri. Tiadanya pemerintahan pusat yang kuat dan degradasi moral di kalangan pejabat pemerintahan mendorong sejumlah kaum terpelajar bangkit dan mulai memikirkan bagaimana mendorong masyarakat berusaha menata kembali kehidupan sosial dan moral mereka dengan baik.

Kaum bangsawan terpelajar ini telah tersingkir dari kehidupan politik dan pemerintahan, karena pada saat negeri dilanda kekacauan dan perang yang diperlukan ialah para jenderal dan pengambil kebijakan politik. Dinasti Chou sendiri telah lebih satu abad memerintah negeri Cina. Pemerintahan mereka semula berjalan baik, tindakan hukum berjalan sebagaimana diharapkan dan ketertiban telah terbangun dengan baik. Dinasti Chou berhasil membangun tradisi pemikiran Cina yang selama berabad-abad mempengaruhi pemikiran orang Cina. Misalnya kebiasaan menghormati leluhur dengan melaksanakan berbagai upacara keagamaan dan kegemaran akan sejarah masa lalu.

Dalam upaya untuk mendapat legitimasi atas kekuasaannya Dinasti Chou menafsirkan kembali sejarah Cina. Misalnya saja penaklukan yang dilakukannya atas dinasti sebelumnya, Shang, dikatakan sebagai amanat dari dewa-dewa yang bersemayam di Kayangan. Penguasa dinasti Shang dikatakan telah banyak melakukan kejahatan di bumi sehingga tidak direstui oleh leluhur mereka, dan dewa-dewa di Kayangan membencinya serta memberikan mandat kepada penguasa Dinasti Chou untuk menggantikannya sebagai pemegang tampuk pemerintahan.

Dalam perkembangan selanjutnya ternyata penyelenggaraan upacara-upacara menghormati leluhur itu lebih merupakan pemborosan. Sering sebuah upacara dilakukan secara berlebihan untuk memamerkan kekayaan dari keluarga yang menyelenggarakannya. Pemerintah pusat dan penguasa wilayah berlomba-lomba memungut pajak yang tinggi, memeras rakyat dan menggiring mereka melakukan kerja paksa. Para bangsawan, jenderal dan pejabat berlombalomba melakukan korupsi dan penyelewengan, menimbun harta dan kekuasaan. Mereka saling menghasut sehingga perpecahan tidak bisa dihindari lagi dan peperangan silih berganti muncul antara penguasa wilayah yang satu dengan penguasa yang lain.

Dilatarbelakangi keadaan seperti itu filsafat Cina lebih banyak memusatkan perhatian pada persoalan politik, kenegaraan dan etika. Kecenderungan inilah yang membuat filsafat Cina memiliki ciri yang berbeda dari filsafat India, Yunani dan Islam.

Berbeda dengan filsafat Yunani, filsafat Cina Kuno memandang soal perubahan dan transformasi sebagai sebuah sifat dunia yang tidak bisa direduksikan lagi, termasuk di dalamnya benda-benda dan manusia itu sendiri. Ada perbedaan yang mencolok antara Filsafat Cina dengan filsafat Barat. Filsafat Cina menekankan pada perubahan, becoming, waktu dan temporalitas, dan tidak hanya membedakan metafisika Cina tentang realitas dan alam dari trend utama tradisi filsafat Barat tetapi juga dari orientasi filsafat India.

Bagi para filsuf Cina, pengalaman akan perubahan dalam dunia justru membuat mereka masuk dalam alam dunia yang sejati dan dalam diri manusia sendiri. Di dalamnya, ada kemungkinan bagi terjadinya perkembangan, transformasi, interaksi dan integrasi.

\section{Periodisasi Filsafat Cina}

Pada perkembangan melewati rentan waktu panjang yang dilalui Filsafat di Cina, disini Filsafat Cina dapat dikategorikan ke dalam empat periode besar. 


\section{Jaman Klasik (600-200 S.M.)}

Menurut tradisi, periode ini ditandai oleh seratus sekolah filsafat:seratus aliran yang semuanya mempunyai ajaran yang berbeda. Namun, kelihatan juga sejumlah konsep yang dipentingkan secara umum, misalnya "tao" ("jalan"), "te" ("keutamaan" atau "seni hidup"), "yen" ("perikemanusiaan"), “i” ("keadilan"), "t'ien" ("surga") dan "yin-yang" (harmoni kedua prinsip induk, prinsip aktif-laki-laki dan prinsip pasif-perempuan). Sekolah-sekolah terpenting dalam jaman klasik adalah sebagai berikut.

\section{a) Konfusianisme}

Konfusius (bentuk Latin dari nama Kong-Fu-Tse, "guru dari suku Kung") hidup antara 551 dan 497 S.M. la mengajar bahwa Tao ("jalan" sebagai prinsip utama dari kenyataan) adalah "jalan manusia". Artinya: manusia sendirilah yang dapat menjadikan Tao luhur dan mulia, kalau ia hidup dengan baik. Keutamaan merupakan jalan yang dibutuhkan. Kebaikan hidup dapat dicapai melalui perikemanusiaan ("yen"), yang merupakan model untuk semua orang. Secara hakiki semua orang sama walaupun tindakan mereka berbeda.

\section{b) Taoisme}

Taoisme diajarkan oleh Lao Tse ("guru tua") yang hidup sekitar 550 S.M. Lao Tse melawan Konfusius. Menurut Lao Tse, bukan "jalan manusia" melainkan "jalan alam"-lah yang merupakan Tao. Tao menurut Lao Tse adalah prinsip kenyataan objektif, substansi abadi yang bersifat tunggal, mutlak dan tak-ternamai. Ajaran Lao Tse lebih-lebih metafisika, sedangkan ajaran Konfusius lebih-lebih etika. Puncak metafisika Taoisme adalah kesadaran bahwa kita tidak tahu apa-apa tentang Tao. Kesadaran ini juga dipentingkan di India (ajaran "neti", "na-itu": "tidak begitu") dan dalam filsafat Barat (di mana kesadaran ini disebut "docta ignorantia", "ketidaktahuan yang berilmu").

\section{c) Yin-Yang}

"Yin" dan "Yang" adalah dua prinsip induk dari seluruh kenyataan. Yin itu bersifat pasif, prinsip ketenangan, surga, bulan, air dan perempuan, simbol untuk kematian dan untuk yang dingin. Yang itu prinsip aktif, prinsip gerak, bumi, matahari, api, dan laki-laki, simbol untuk hidup dan untuk yang panas. Segala sesuatu dalam kenyataan kita merupakan sintesis harmonis dari derajat Yin tertentu dan derajat Yang tertentu.

\section{d) Moisme}

Aliran Moisme didirikan oleh Mo Tse, antara 500-400 S.M. Mo Tse mengajarkan bahwa yang terpenting adalah "cinta universal", kemakmuran untuk semua orang, dan perjuangan bersamasama untuk memusnahkan kejahatan. Filsafat Moisme sangat pragmatis, langsung terarah kepada yang berguna. Segala sesuatu yang tidak berguna dianggap jahat. Bahwa perang itu jahat serta menghambat kemakmuran umum tidak sukar untuk dimengerti. Tetapi Mo Tse juga melawan musik sebagai sesuatu yang tidak berguna, maka jelek.

\section{e) Ming Chia}

Ming Chia atau "sekolah nama-nama", menyibukkan diri dengan analisis istilah-istilah dan perkataan-perkataan. Ming Chia, yang juga disebut "sekolah dialektik", dapat dibandingkan dengan aliran sofisme dalam filsafat Yunani. Ajaran mereka penting sebagai analisis dan kritik yang mempertajam perhatian untuk pemakaian bahasa yang tepat, dan yang memperkembangkan logika dan tatabahasa. Selain itu dalam Ming Chia juga terdapat khayalan tentang hal-hal seperti "eksistensi", "relativitas", "kausalitas", "ruang" dan "waktu".

\section{f) Fa Chia}

Fa Chia atau "sekolah hukum", cukup berbeda dari semua aliran klasik lain. Sekolah hukum tidak berpikir tentang manusia, surga atau dunia, melainkan tentang soal-soal praktis dan politik. Fa Chia mengajarkan bahwa kekuasaan politik tidak harus mulai dari contoh baik yang diberikan oleh kaisar atau pembesar-pembesar lain, melainkan dari suatu sistem undang-undang yang keras sekali.

Tentang keenam sekolah klasik tersebut, kadang-kadang dikatakan bahwa mereka berasal dari keenam golongan dalam masyarakat Cina. Berturut-turut: (1) kaum ilmuwan, (2) rahib-rahib, (3) okultisme (dari ahli-ahli magi), (4) kasta ksatria, (5) para pendebat, dan (6) ahli-ahli politik. 


\section{Jaman Neo-Taoisme dan Buddhisme (200 S.M.-1000 M.)}

Bersama dengan perkembangan Buddhisme di Cina, konsep Tao mendapat arti baru. Tao sekarang dibandingkan dengan "Nirwana" dari ajaran Buddha, yaitu "transendensi di seberang segala nama dan konsep", "di seberang adanya".

\section{Jaman Neo-Konfusianisme (1000-1900)}

Dari tahun $1000 \mathrm{M}$. Konfusianisme klasik kembali menjadi ajaran filsafat terpenting. Buddhisme ternyata memuat unsur-unsur yang bertentangan dengan corak berpikir Cina. Kepentingan dunia ini, kepentingan hidup berkeluarga dan kemakmuran material, yang merupakan nilai-nilai tradisional di Cina, sema sekali dilalaikan, bahkan disangkal dalam Buddhisme, sehingga ajaran ini oleh orang dianggap sebagai sesuatu yang sama sekali asing.

\section{Jaman Modern (setelah 1900)}

Sejarah modern mulai di Cina sekitar tahun 1900. Pada permulaaan abad kedua puluh pengaruh filsafat Barat cukup besar. Banyak tulisan pemikir-pemikir Barat diterjemahkan ke dalam bahasa Cina. Aliran filsafat yang terpopuler adalah pragmatisme, jenis filsafat yang lahir di Amerika Serikat. Setelah pengaruh Barat ini mulailah suatu reaksi, kecenderungan kembali ke tradisi pribumi. Terutama sejak 1950, filsafat Cina dikuasai pemikiran Marx, Lenin dan Mao Tse Tung.

Inilah sejarah perkembangan filsafat China, yang merupakan filsafat Timur. Yang termasuk kepada filsafat Barat misalnya filsafat Yunani, filsafat Helenisme, "filsafat Kristiani", filsafat Islam, filsafat jaman renaissance, jaman modern dan masa kini.

\section{Tokoh Filsafat Cina}

1. Confusionisme

Kong Hu Cu merupakan seorang filosof besar Cina. Dialah orang pertama pengembang sistem yang memadukan alam fikiran dan kepercayaan orang Cina yang paling besar filosofinya menyangkut moralitas orang perorang dan konsepsi suatu pemerintahan tentang cara-cara melayani rakyat dan memerintahnya lewat tingkah laku teladan yang sekarang telah menyerap dalam kehidupan dan kebudayaan orang Cina selama lebih dari dua ribu tahun. Dari pengaruh pemikiran inilah Confusianisme banyak menghasilkan para intelektual di Cina, dan pengaruh intelektualnya ini berpengaruh terhadap sebagian penduduk di dunia.

\section{a. Filsafat Confusianisme}

Confusius atau yang disebut juga Kong Fu Tse. la dilahirkan pada tahun 551 SM di daerah Lu,di Shantung. Raja Wu Wan telah memberikan daerah itu kepada Chou. Negeri Lu yang aman dan makmur beribu kota Chufu. Confusius pindah ke Chufu. Pada usia muda yakni 17 tahun, ia diangkat menjadi pengawas kerajaan, sebagai pemilik ladang gandum umum dan lumbung pangeran, kemudian menjadi Kepala Peternakan. la seorang yang suka belajar. Pada usia 22 tahun ia mulai mengajar.

Setahun kemudian ia ditinggalkan ibunya. Menurut adat, ia harus mengundurkan diri dari keramaian untuk berduka cita selama tiga tahun. Keadaan kacau pada masa itu menyebabkan ia tidak taat pada adat. Sikap Confusius sangat dihormati, terutama oleh murid-muridnya yang setia. Selama berduka cita, yaitu selama tiga tahun itulah ia mendalami kesusastraan, sejarah, dan adat istiadat dari zaman Wen sampai Mu yang tersimpan dalam perpustakaan kerajaan.

Confusius yakin bahwa untuk mengamankan keadaan, maka harus kembali pada jalan yang telah ditempuh oleh yao dan Shun,yaitu dengan jalan berbakti dan setia. la belajar lagi dari semua buku-buku yang ada tentang agama, adat, sastra, sejarah, musik, dan lain-lain. Kemudian semuanya itu digubah dan disadur sehingga berbentuk pedoman hidup bangsa Cina. Setelah habis masa duka citanya ia mengunjungi loyang yang dibangun oleh Pangeran Chou. la mulai lagi mengajarkan pada murid-muridnya tentang sejarah, kesusastraan, perihal upacara, musik syair, dan terus mencatat segala hal yang berarti dan diketahuinya dalam tulisan yang berjudul "The Books of History (Shang Shu), The pring and Autum Annals, The Books of Rites, dan The Book of Song.

\section{b. Filsafat Confusianisme dan Pengaruhnya}

Pemikiran Confusianisme yang didasarkan atas prinsip keseimbangan yin dan yang. Prinsip keseimbangan menjadi hal utama yang dibahas sehingga keseimbangan yang mengatur 
hidup kita juga seimbang. Dengan aturan keseimbangan ini memberikan dampak yang begitu besar khususnya bagi masyarakat Cina.

Confusius menganjurkan agar orang belajar dan mempraktekan apa yang dipelajari sehingga menjadi seorang intelektual yang lengkap, orang seperti ini beliau sebut sebagai Qun $\mathrm{Zi}$ atau seorang intelektual-bijaksana,selain itu dia harus tatap tenag dalam segala situasi agar dapat menyelesaikan persoalan-persoalan penghidupan dengan rasional. Ajaran Confusianisme mengajarkan bahwa kita harus bisa mengatur harta yang baik terutama pendidikan anak-anak. Unsur pendidikan ini dalam Confusianisme karena para cendikiawan dihormati jauh lebih tinggi dibandingkan kekayaan. Itulah sebabnya di Amerika saat ini kebanyakan mahasiswa peringkat atas diduduki oleh orang-orang dari Hong Kong, Cina, Taiwan, Singapore, Korea, dan Jepang yang ternyata negara-negara tersebut dipengaruhi ajaran Confusianisme.

Kemudian daripada itu ajaran Confusianisme berdampak pula pada ekonomi Cina itu sendiri. Dengan adanya konsep kerja keras dan kekerabatan yanmg dijunjung tinggi, merupakan jaminan link keberhasilan ekonomi masyarakat Cina secara keseluruhan. Selain itu faktor kecintaan terhadap negara induk (RRC), menjadi sebuah motivasi besar bagi mereka, untuk berusaha seoptimal mungkin agar mampu memberikan kontribusi bagi negaranya tersebut, sekalipun mereka hidup di negara orang lain.

Secara ekonomi Cina memang mempunyai kompeten yang besar, bahkan Amerika sekalipun segai sebuah negara super power merasa riskan dengan keberadaan Cina tersebut. Selain faktor kerja keras, kekerabatan, faktor jumlah penduduk yang besar dan tersebar dimanamana mempunya andil besar dalam roda perekonomian Cina. Kemudian daripada itu, tradisi kultural yang lekat dengan kehidupan orang Cina, merupakan faktor penetralisir, serta pendorong upaya pencerahan bagi kehidupan yang jauh lebih baik.

Bagi orang Cina sendiri keberadaan faktor ekonomi secara otomatis merupakan faktor pendukung majunya pendidikan (kemajuan intelektual). Filsafat Timur dianggap lebih magis dan bersifat irasional. Namun, ajaran Confusianisme yang termasuk filsafat Cina ini yang sebenarnya bukan aliran agama, tetapi aliran falsafah hidup yang tidak mengesampingkan dasar-dasar kepercayaan lama, sehingga mampu memelihara kerukunan dan kesejahteraan dalam negeri Cina dalam waktu tak kurang dari dua ribu tahun.

Orang Barat mengangap filsafat pemikiran Timur terutama Cina tidak selalu bersifat rasio (irasional) namun, dari uraian pengaruh confusianisme di atas terlihat jelas bahwa pemikiran confusianisme ini bersifat nalar rasional karena pemikiran ini sesuai dengan kehidupan seharihari orang Cina. Namun, pendapat tersebut bisa dibantah ternyata pada masa kejayaan Eropa 300 tahun yang lalu, banyak sarjana dan kaum intelektual terinspirasi oleh ajaran Khonghucu. salah satu diantara mereka adalah Gottfried Wilhelm Von Leibniz, bahkan mengusulkan pada tahun1689 suatu program pertukaran budaya Timur-Barat, mungkin usul pertukaran budaya ini merupakan pertukaran pertama internasional. dari pertukaran budaya diatas terlihat bahwa sekarang ini filsafat cina tidak lagi magis dan Irrasional, malahan filsafat Confusianisme ini bisa mempengaruhi perkembangan pemikiran di dunia.

Konfusius mengubah political ren ke dalam suatu moral and human ren. Ada 3 point yang ditunjukkan. Yang pertama, belas kasih dan kebajikan terhadap orang-orang secara umum diperluas dengan melibatkan unsur perasaan dan tindakan pribadi individu dalam masyarakat. Yang kedua, bukanlah penguasa itu sendiri yang mampu untuk mempraktekan ren atau yang harus mempraktikannya. Semua manusia mampu mempraktekkannya dan harus mempraktekannya supaya lebih manusiawi dan dimanusiakan. Yang ketiga, ren harus dipandang sebagai kekuatan batin dari seorang pribadi manusia, yang dapat dilatihkan dan yang membutuhkan adanya perhatian yang konstan supaya dapat tumbuh ke dalam sebuah kesempurnaan.

\section{Taoisme \\ a. Filsafat Taoisme}

Sebagai suatu ajaran filosofis, Taoisme didirikan oleh Lao Tzu pada abad keenam sebelum Masehi. Ajaran ini terus berkembang sampai abad kedua sebelum Masehi. Filsafat Taoisme juga terdiri dari aliran Chuang Tzu dan Huang Lao. Di dalam ajaran-ajaran awal tentang Taoisme ini, Tao dipandang sebagai "sumber yang unik dari alam semesta dan menentukan semua hal; bahwa semua hal di dunia terdiri dari bagian yang positif dan bagian yang negatif; dan bahwa semua yang berlawanan selalu mengubah satu sama lain; dan bahwa orang tidak boleh melakukan tindakan yang tidak alami tetapi mengikuti hukum kodratnya." Sikap pasrah terhadap hukum kodrat dan hukum alam ini disebut juga sebagai wu-wei. 
Di dalam masyarakat Cina kuno, filsafat dan agama belumlah dibedakan secara tegas. Sejak Taoisme mulai dikenal di dalam dunia berbahasa Inggris, pembedaan antara Taoisme sebagai filsafat dan Taoisme sebagai agama belumlah ada. Pada pertengahan 1950, para ahli sejarah dan Filsafat Cina berpendapat bahwa ada perbedaan tegas di antara keduanya, walaupun memang keduanya berdiri di atas tradisi yang sama. Marcel dan Granet dan Henri Maspero adalah orang-orang yang melakukan penelitian mendalam di bidang ini.

Memang, ada keterkaitan erat antara filsafat Taoisme dan agama Taoisme. Para filsuf Tao sendiri dianggap sebagai pendiri Taoisme, baik sebagai filsafat maupun sebagai agama. Buku paling awal yang memuat ajaran Tao ini berjudul Classic of Great Peace (T'ai-p'ing Ching) yang dianggap merupakan tulisan tangan langsung dari Lao Tzu. Dalam arti tertentu, Lao Tzu sendiri seringkali dianggap sebagai „dewa“. Ia punya beberapa julukan, seperti „Saint Ancestor Great Tao Mysterious Primary Emperor", dan „Yang memiliki status sebagai Dewa“ (The Divine) itu sendiri.

Perbedaan dasar antara filsafat Taoisme dan agama Taoisme juga terletak pemahaman tentang tujuan dari keberadaan manusia itu sendiri. Para filsuf Taois berpendapat bahwa tujuan setiap orang adalah mencapai transendensi spiritual. Oleh sebab itu, mereka perlu menekuni ajaran Tao secara konsisten. Sementara, para pemuka agama Taoisme berpendapat bahwa tujuan setiap manusia adalah untuk mencapai keabadian, terutama keabadian tubuh fisik (physical immortality) yang dapat dicapai dengan hidup sehat, sehingga bisa berusia panjang. Pada titik ini, kedua ajaran Taoisme ini berbeda secara tajam. Para filsuf Taoisme berpendapat bahwa usia panjang itu tidaklah penting. "Hanya orang-orang yang tidak mencari kehidupan setelah mati", demikian tulis Lao Tzu di dalam Tao Te Ching pada bagian ke-13, "yang lebih bijaksana di dalam memaknai hidup." Di dalam beberapa tulisannya, Chuang Tzu menyatakan, "Orang-orang Benar pada masa kuno tidak mengetahui apapun tentang mencintai kehidupan, dan mereka juga tidak mengetahui apapun tentang membenci kematian." Lao Tzu juga menambahkan, "Hidup dan mati sudah ditakdirkan - sama konstannya dengan terjadinya malam dan subuh... manusia tidak dapat berbuat apapun tentangnya."

Jelaslah bahwa para filsuf besar Taoisme menyatakan bahwa orang tidaklah perlu untuk memilih antara kehidupan atau kematian. Alih-alih hidup di dalam keresahan di antara keduanya, orang harus melampaui perbedaan di antara keduanya. "Sikap transenden dari filsafat Taoisme terhadap hidup dan kematian", demikian tulis Xiaogan, ".....adalah mengikuti alam dan tidak melakukan tindakan-tindakan yang tidak alamiah". Sikap mengikuti alam disebut juga sebagai tzu-jan, dan sikap pasif dengan tidak melakukan tindakan-tindakan yang tidak alami disebut juga sebagai wu-wei. Kontras dengan itu, Taoisme sebagai agama justru menekankan pentingnya keabadian jiwa sebagai prinsip utama.

Filsafat Taoisme dan agama Taoisme juga berbeda pendapat tentang bagaimana seharusnya orang bersikap di hadapan penguasa politik. Filsafat Taoisme menolak tradisi (antitraditional) dan berupaya melampaui nilai-nilai yang diakui bersama. Lao Tzu dan Chuang Tzu bersikap kritis terhadap penguasa pada jamannya, dan juga terhadap nilai-nilai Konfusianisme tradisional. Mereka berdua berpendapat bahwa masyarakat akan jauh lebih baik, jika semua bentuk aturan, moralitas, hukum, dan penguasa dihapuskan. Di sisi lain, para pemuka agama Taoisme sangat menghormati penguasa dan aturan-aturan Konfusianisme. "Orang-orang yang hendak memiliki keabadian", demikian tulis Ko Hung (284-343), seorang pemuka agama Taoisme, "haruslah menempatkan kesetiaan kepada penguasa dan kesalehan yang tulus kepada orang tua mereka... sebagai prinsip dasar." K'ou Ch'ien Chih, seorang pemuka agama Toaisme lainnya, juga berpendapat bahwa setiap orang haruslah mempelajari Konfusianisme, serta secara aktif membantu kaisar di dalam mengatur dunia.

Agama Taoisme memang memberikan perhatian besar pada kepentingan-kepentingan praktis yang bersifat temporal. Jika filsafat Taoisme lebih bersifat individualistik dan kritis, maka agama Taoisme dapat dipandang sebagai ajaran yang lebih bersifat sosial dan praktis. Dalam arti ini, para filsuf Taoisme memiliki pengertian-pengertian yang agak berbeda tentang konsepkonsep dasar Taoisme, seperti wu-wei, Tao, dan te, jika dibandingkan dengan pengertian para pemuka agama Taoisme.

\section{Pandangan Pragmatisme Mengenai Hubungan Alam dan Manusia}

Faham pragmatisme merupakan cerminan dari life style masyarakat Amerika pada umumnya. Pragmatisme merupakan sebuah aliran yang berusaha menengahi antara tradisi empirisme dan tradisi idealisme. Menurut tokoh pragmatisme John Dewey filsafat merupakan pengatur kehidupan dan aktivitas manusia secara lebih baik, untuk di dunia, dan sekarang. 
Pandangan Dewey tersebut membuat kemajuan yang linear pada masyarakat Barat. Manusia Barat terobsesi untuk melakukan berbagai eksperimen mengenai alam dan ternyata hal ini mewujudkan penemuan-penemuan mutakhir di zamannya.

Dalam pandangan pragmatisme manusia dan alam dipandang sebagai sesuatu yang selalu saling bersandar. Manusia bukan dua bagian yang berbeda antara jiwa dan badan, ia bersatu dengan alam dan alam di interpretasikan sehingga mencakup manusia. Alam dalam manusia adalah alam yang sudah berfikir dan menjadi cerdas. Alam dikatakan tidak rasional dan tidak irrasonal. Alam dapat difikirkan sekaligus difahami. Alam dipandang sebagai sesuatu yang harus dirubah dan dikontrol melalui eksperimen-eksperimen. Nietzsche mendambakan manusia yang terbaik adalah mereka yang mampu mengatasi segala keterbatasannya. Jika ia telah mampu mengatasi hal tersebut ialah yangdinamai oleh Nietzsche sebagaiUbber mench (superman). Manusia diyakini sebagai makhluk yang multidimensional maka dari itu sangat sulit untuk menafsirkan secara menyeluruh dan tepat apa yang menjadi keinginan dan tujuan dari hidupnya.

Pragmatisme yang telah mendominasi masyarakat Barat merupakan sebuah pencapaian filsafat yang sangat bagus, filsafat yang semula hanya berhenti pada masalah-masalah yang bersifat esensial danutopis oleh faham pragmatisme telah dilahirkan ke dalam dunia. Pragmatisme menekankan pada pendirian dan metode lebih daripada doktrin filsafat yang sistematis. Teori kebenaran yang diungkapkan oleh seorang tokoh pragmatisme, William James mengatakan bahwa suatu ide itu benar jika ia berhasil dan memberi akibat-akibat yang memuaskan. Oleh sebab itu kebenaran bersifat relatif dan terus berkembang. Kebenaran (truth) adalah yang menjadikan berhasil dalam cara kita berfikir.

Asas kegunaan atas hasil dari sebuah tindakan oleh masyarakat pragmatis telah biasa disalahartikan sebagai sebuah dalil pembenaran atas terjadinya eksploitasi alam. Pembangunan pabrik dengan dampak polusi yang tinggi diperbolehkan dengan dalih untuk membuka lapangan kerja yang luas sekaligus guna mengurangi tingkat pengangguran di sebuah wilayah. Demikian dalil asas manfaat tersebut terus bergulir hingga sekarang. Dominasi masyarakat industri maju terhadap negara berkembang menggunakan alasan-alasan pragmatis pun akhirnya tidak dapat dihindari lagi. Paham tentang pragmatisme membawa sebuah egoisme manusia. Perkembangan di Barat ternyata membawa dampak bagi masyarakat di Timur. Ekspansi masyarakat Barat guna mencari bahan baku bagi industri di negaranya berubah menjadi penjajahan terhadap negara yang memiliki bahan baku .

Dengan alasan ekonomisnya masyarakat Barat, negara berkembang hanya dijadikan sebagai sebuah obyek penderita dari pasar bebas, dimana kekurangan teknologi informasi dan pendidikan menjadikan negara berkembang hanya menjadi konsumen. Meskipun negara berkembang telah menghasilkan berbagai bahan baku guna kelanjutan produksi industri di negara maju akan tetapi pengelolaan dan pangsa pasar atas bahan baku tersebut tetap di kendalikan oleh masyarakat yang mempunyai andil besar terhadap kemajuan teknologi. Sebagai contoh kongkrit atas hal tersebut ialah, bagaimana produk seperti kopi yang bahan bakunya berasal dari Indonesia setelah diolah oleh produsen asing ditambah berbagai pengembangan rasa danpackaging yang bagus, produk tersebut seakan telah berubah menjadi produk luar yang hilang sama sekali asalnya (bahan bakunya).

Selain memenuhi berbagai kebutuhan bagi industri, masyarakat Barat juga berusaha menyebarkan ajaran-ajaran yang ada di negaranya. Dari sini terjadilah sebuah pembauran budaya asli dengan budaya luar. Tuntutan zaman serta mudahnya akses informasi semakin memudahkan masuknya budaya-budaya luar. Budaya Barat yang telah dikonsumsi secara sembarangan menimbulkan beralihnya pola pikir masyarakat Timur dari identitas aslinya beralih ke Barat. Ini dapat diperhatikan dalam gaya hidup remaja. Menurut mereka yang populis adalah apa yang menjadi tren di dunia Barat.

Arus globalisasi menawarkan sebuah standarisasi disegala hal, mudai dari bahasa, life style, cara berpakaian dan lain-lain. Hal ini juga menimbulkan tuntutan tehadap sebuah ideologi yang mendukung globalisasi. Akibatnya negara-negara berkembang hanya menjadi objek zaman, ia tidak dapat menentukan arah dari perkembangan zaman.Peradaban Timur memang dirasa lamban sekali menuju kemajuan, tidak seperti di Barat yang disimbolkan kemajuan sebagai garis linear, di Timur perkembangan zaman digamba rkan sebagai sebuah spiral yang meskipun lamban akan tetapi mempunyai landasan yang kokoh. 


\section{Prinsip Yin-Yang Sebagai Sebuah Pandangan Alternatif Manusia Terhadap Pendidikan Alam}

Salah satu ajaran yang terkenal dari filsafat Cina pada Jaman Klasik adalah Prinsip "Yin Yang". Ajaran "Yin Yang" berasal dari filsafat Tionghoa dan metafisika kuno yang menjelaskan setiap benda di alam semesta memiliki polaritas abadi berupa dua kekuatan utama yang selalu berlawanan tapi selalu melengkapi. Yin bersifat pasif, sedih, gelap, feminin, responsif, dan dikaitkan dengan malam. Yang bersifat aktif, terang, maskulin, agresif, dan dikaitkan dengan siang. Yin disimbolkan dengan air, sedangkan Yang disimbolkan dengan api. Selain itu "Yin Yang" adalah dua prinsip induk dari seluruh kenyataan atau yang secara harfiah artinya positif dan negatif, namun implisit mewakili makna yang sangat mendalam tentang dualisme yang saling bertentangan, namun saling melengkapi dalam menyokong kehidupan dan mekanisme universal. Prinsip Yin Yang dalam bahasa Tionghoa perantauan seringkali disebut "Im - Kang". "Im" atau "Yin" mewakili kelembutan yang bersifat pasif, prinsip ketenangan, surga, bulan, air dan perempuan, simbol untuk kematian dan untuk yang dingin. "Kang" atau "Yang" mewakili kekerasan yang bersifat aktif, prinsip gerak, bumi, matahari, api, dan laki-laki, simbol untuk hidup dan untuk yang panas. Prinsip Yin Yang memadukan lembut dan keras dalam kesatuan yang utuh, dan juga memadukan keselarasan alam. Sehingga segala sesuatu dalam kenyataan kita merupakan sintesis harmonis dari derajat "Yin" tertentu dan derajat "Yang" tertentu.

Kemungkinan besar teori Yin dan Yang berasal dari ajaran agama agraris zaman kuno. Konsep Yin Yang dikenal dalam Taoisme dan Konfusianisme, walaupun kata Yin Yang hanya muncul sekali dalam kitab Tao Te Ching yang penuh dengan contoh dan penjelasan tentang konsep keseimbangan.

Dalam pelajaran ilmu alam diketahui bahwa semua benda yang ada di alam semesta terbuat dari atom (benda yang terkecil). Yang membedakan benda satu dengan yang lainnya adalah konfigurasi atom-nya yang berbeda. Misalnya air terdiri dari 2 atom hidrogen dan 1 atom oxigen, dan seterusnya. Atom sendiri bila dipecah tidak lagi merupakan benda tetapi partikel energi yaitu satuan-satuan energi yang bila di-manipulasi secara tepat bisa menghasilkan energi dengan kekuatan yang dahsyat seperti bom atom. Peneliti kosmologi dan orang yang berilmu di zaman dahulu telah menghayati bahwa diseluruh jagat raya termasuk di bumi terdapat "cosmic energy" yang tiada batasnya.

Di Tiongkok sendiri, "cosmic energy" dikembangkan dengan membedakan energy yang bersifat negatif (Yin) dan positif (Yang). Penghayatan yang "dibaur" dengan pandangan Taoism menjadikan prinsip Yin Yang sebagai salah satu prinsip kehidupan bagi rakyat di negeri tersebut. Prinsip yang dipakai untuk menjelaskan segala sesuatu yang berhubungan dengan kehidupan termasuk menjelaskan sifat penyakit dan cara penyembuhannya.

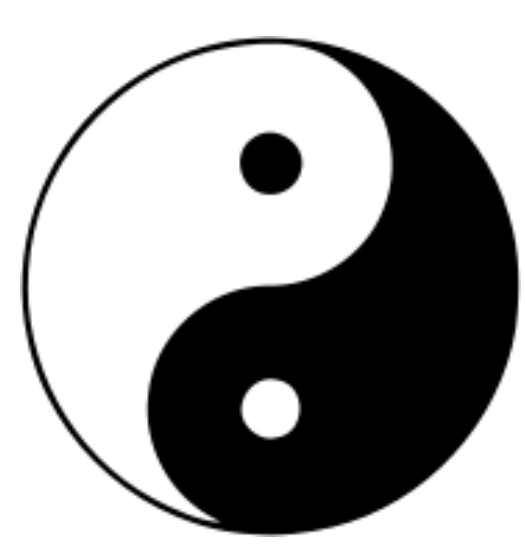

Gambar 1 Simbol Yin Yang

Singkatnya, prinsip Yin Yang (negatif positif) dapat diterapkan karena semua hal memang memiliki sifat dualism. Dingin dan panas, siang dan malam, musim dingin dan musim panas, utara dan selatan, api dan air, perempuan dan laki-laki, genap dan ganjil, feminin dan maskulin, hitam dan putih, bumi dan langit, bumi dan matahari, bundar dan persegi. Prinsip ini rupanya bukan monopoli rakyat disana saja karena masyarakat Bali kita menggunakan kain poleng (bermotif kotak-kotak hitam putih) untuk mengharmoniskan tenaga negatif/positif alam semesta (Dwi Bhineda).

Yang penting diingat adalah prinsip Yin Yang menekankan bahwa tidak ada Yin atau Yang yang mutlak. Segala sesuatu Yin akan memiliki sedikit Yang dan sebaliknya, sesuai dengan gambar T'ai Chi diatas dimana bagian hitam terdapat titik putih dan bagian putih titik hitam. Gambar T'ai Chi ini mengilustrasikan prinsip Yin Yang secara sempurna.

Yin mutlak bila sampai terjadi sama bahayanya dengan Yang mutlak. Contohnya, seorang laki-laki seyogyanya dilahirkan dengan lebih banyak sifat Yang (maskulin) dari pada Yin. Namun bila ia tidak memiliki sedikitpun sifat Yin ia tidak memiliki daya imbang dan ini akan sangat merugikannya. Sebaliknya, Yin dan Yang tidak boleh pula mencapai titik imbang (equilibrium) karena sesuatu yang terlalu seimbang tidak mendatangkan perubahan atau kemajuan. Equilibrium $=$ stagnant $=$ tidak ada kegairahan $=$ kematian . 
Walaupun prinsip Yin Yang sangat ampuh dalam menganalisa "cosmic energy" (Chi), namun ia tidak cukup untuk menyelami seluruh sifat energy. Sehingga dibutuhkan prinsip 5-Unsur yang melihatnya lebih mendalam dengan membaginya menjadi 5 jenis atau sifat energi secara berurutan, dimulai dengan unsur kayu, kemudian api, tanah, besi (atau metal) dan air (lihat gambar dibawah).

Gabungan dari prinsip Yin Yang dan 5-Unsur inilah yang menjadi dasar untuk menganalisa sifat energi dalam astrologi Tiongkok. Penjelasan ke- 5 unsur energi adalah sebagai berikut.

1) Unsur Kayu

Dalam waktu, unsur kayu diartikan sebagai musim semi yaitu mulainya suatu kehidupan baru. Oleh karena itu, ia identik dengan pagi hari, timur dan bersifat angin. Warna hijau. Dalam ilmu pengobatan, hati berunsur kayu. Dalam karakter, unsur kayu diasosiasikan dengan kreativitas dan pelaksanaan (action).

\section{2) Unsur Api}

Dalam waktu, unsur api diartikan sebagai pertengahan musim panas. Oleh karena itu, ia identik dengan di tengah siang hari, selatan dan bersifat panas. Warna merah. Dalam ilmu pengobatan, jantung bersifat api. Dari segi karakter, unsur api diasosiasikan dengan perasaan dan emosi (passion).

3) Unsur Tanah

Dalam waktu, unsur tanah diartikan sebagai awal siang hari. Oleh karena itu, ia identik dengan posisi tengah dan berkaitan dengan kelembaban (humidity). Warna kuning. Dalam ilmu pengobatan, limpa bersifat tanah. Dari segi karakter, unsur tanah diasosiasikan dengan daya konsentrasi, realisme dan stabilitas.

\section{4) Unsur Besi}

Dalam waktu, unsur besi (metal) diartikan sebagai musim gugur. Oleh karena itu, ia identik dengan malam hari, barat dan bersifat kering (aridity). Warna putih. Dalam ilmu pengobatan, paru-paru bersifat metal. Dari segi karakter, unsur besi diasosiasikan dengan kemauan keras dan kemandirian, juga khidmat dan ketajaman.

5) Unsur Air

Dalam waktu, unsur air diartikan sebagai musim dingin. Oleh karena itu, ia identik dengan malam hari, utara dan bersifat dingin. Warna hitam. Dalam ilmu pengobatan, ginjal bersifat air. Dari segi karakter, unsur air diasosiasikan dengan kejernihan pikiran dan rasional. la mengalir, liberal dan fleksibel.

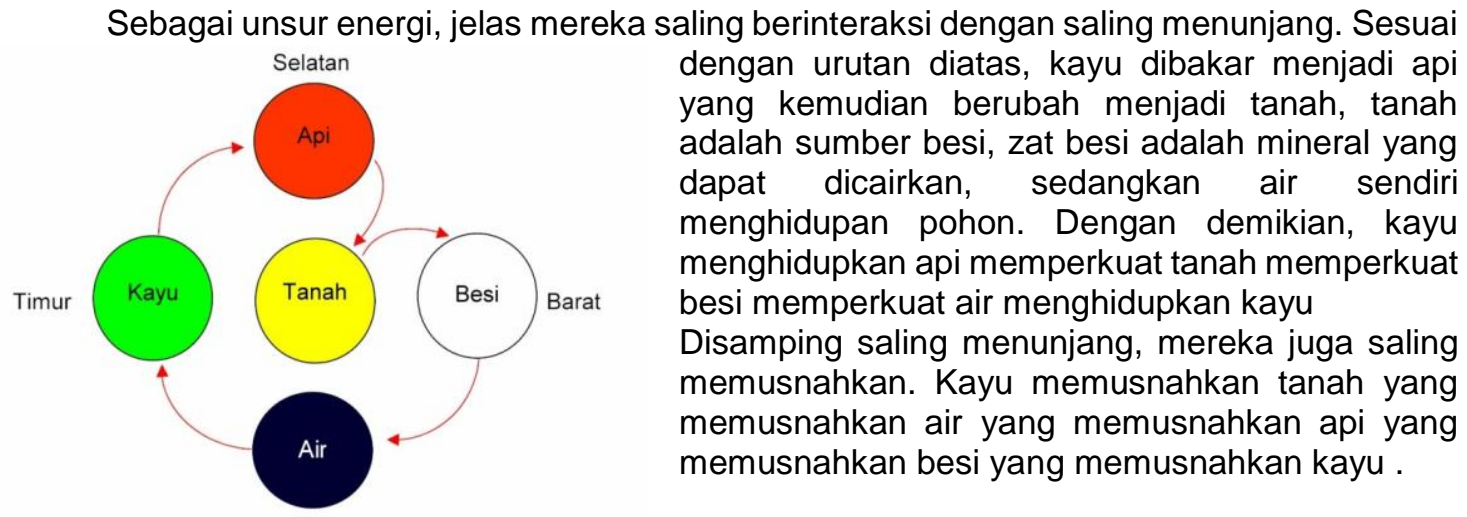

Gambar 2 Interaksi antar Unsur Menunjang 


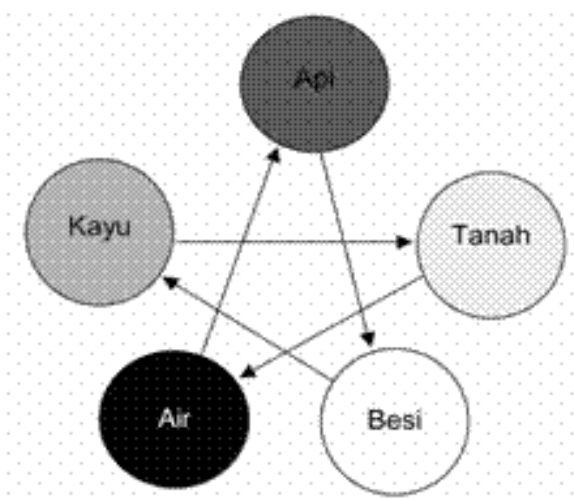

Gambar 3 Unsur yang Memusnahkan
Interaksi menunjang dan memusnahkan inilah yang membuat alam kehidupan dalam keadaan berimbang dan berevolusi terus menerus. Jelas bahwa kedua sumber energi yang saling menunjang dan memusnahkan ini sangat dibutuhkan. Tidak dapat dibayangkan apa yang akan terjadi pada alam semesta bila hanya ada tenaga menunjang tanpa ada yang memusnahkan atau sebaliknya kesimpulan yang lebih mendalam mengenai 5-Unsur harus dikaitkan dengan 4-Pilar (atau 8-Tanda).

4-Pilar adalah suatu pemikiran astrologi yang tercatat dalam "Oracular Inscriptions" yaitu catatan tertua yang pernah ditemukan di daratan Tiongkok paling tidak 1.500 tahun sebelum Masehi atau 3.500 tahun yang lalu pada masa dinasti Shang. Peradaban Tiongkok kuno yang lebih dikenal dengan sebutan peradaban basin sungai Kuning (Huang $\mathrm{Ho}$ ) adalah satu dari empat peradaban tertua manusia yang diketahui sampai saat ini. Tiga lainnya adalah peradaban Mesir, Indus dan Mesopotamia.

Secara singkatnya, 4-Pilar adalah 4-pasang aksara (8 aksara/angka) gabungan hasil perhitungan dari tanggal lahir anda yang melambangkan atau menggambarkan suatu suratan langit dan bumi. Dengan demikian, setiap tanggal lahir dapat "diterjemahkan" atau diuraikan dalam gabungan 8 aksara tersebut. Kombinasi 8 aksara ini merupakan pilar atau inti tersirat (suratan) dari kehidupan orang tersebut.

Pilar pertama yaitu pilar tahun adalah interpretasi dari tahun lahir kita, dan 3 pilar berikutnya yaitu pilar bulan, pilar hari dan pilar jam masing-masing juga hasil interpretasi dari bulan, hari dan jam lahir kita.

Dalam dunia astrologi Tiongkok, dapat dikatakan 4-Pilar adalah perhitungan astrologi yang paling mendasar karena ia merupakan bagian yang tidak terpisahkan dari sistim waktu dan penanggalan Imlek (Lunar Calendar) yaitu penanggalan yang resmi digunakan oleh masyarakat Tionghoa di seluruh dunia termasuk Taiwan, Singapura, HongKong dan Daratan Tiongkok. Misalnya tahun 2003 dalam penanggalan Imlek adalah tahun 2554 namun tahun tersebut lebih dikenal dengan sebutan tahun Kuei Wei. Aksara Kuei adalah aksara ke-10 dalam serial Celestial Stems sedangkan aksara Wei adalah aksara ke-8 dari Terrestrial Branches.

Penerapan prinsip keseimbangan Yin Yang dapat terlihat pada bangunan Phaeno Science Center di Wofsburg, Germany. Karya Zaha Hadid yang satu ini, teraplikasi pada penggunaan material yang saling berlawanan, antara yang solid dengan yang transparant, antara yang tegak dengan miring, antara yang memantulkan cahaya dengan yang menyerap cahaya.

Penggunaan kaca, beton, logam, sebagai material bangunan yang disusun dengan acak akan menambah kuat kesan "ada" karena ada yang "tidak ada", dalam artian sesuatu yang transparan akan ada jika sesuatu yang masif ada, berdiri tegak akan ada jika sesuatu yang miring hadir melengkapinya, dan material yang memantulkan cahaya akan terasa jika yang menyerap cahaya ikut hadir bersama - sama.

Hotel Marques de Riscal ini difungsikan sebagai tempat peristirahatan atau penginapan. Perbedaan yang menghasilkan keseimbangan Yin Yang juga terdapat pada bangunan karya Frank O Gehry ini.

Permukaan yang dibuat sedemikian bergelombangnya dengan penggunan material titanium merah muda dan emas dengan stainlesssteel sebagai finishing begitu kuat memiliki kesan "ada" dari yang "tidak ada" (geometris). Maksudnya sesuatu yang bergelombang dan dapat memantulkan sinar tersebut akan dapat dirasakan jika sesuatu ( permukaan ) yang geometris dengan bahan berupa sandstone dan tidak dapat memantulkan sinar itu ada.

Demikian pula sesuatu bentuk yang solid dan masif akan begitu terasa jika berdiri pula sesuatu yang bergelombang dan berupa kerangka-kerangka yang miring.

Bangunan ini berlokasi di Copenhagen, Denmark. Bangunan ini dibangun diatas lahan seluas $1.150 \mathrm{~m}^{2}$. Bangunan ini merupakan sebuah museum, selain baerfungsi sebagai museum, bangunan ini juga merupakan suatu galeri lukisan. Pembangunan museum ini dimulai tahun 
1918, awalnya bangunan ini berfungsi sebagai galeri seni atau lukisan, namun pada awal tahun 1953 bangunan ini mulai dipublikasikan sebagai museum. Museum ini mengalami perombakan total, dan didesain ulang oleh Zaha Hadid dan akhirnya museum ini rampung dibangun bulan Agustus 2005. Museum ini terlihat sangat dinamis, menyatu dengan alam.

Konsep sang arsitek, Zaha Hadid memang menekankan pada fasad bangunan yang dinamis, tidak kacau namun tetap memiliki unsur kesatuan yang sangat kuat diantara elemenelemen penyusunnya. Sehingga melahirkan sebuah karya bangunan dekonstruksi yang kompleks. Bangunan ini terletak di dalam site yang dikelilingi pepohonan, penataan pohon yang menutupi seluruh area site menambah kesan menyatu dengan alam.

Pada Museum ini ditampilkan perpaduan penggunaan bahan yang kontras dengan lingkungan, seperti penggunaan kaca dan elemen struktur baja yang diekspose sehingga menampilkan suasana yang sangat kontras dengan lingkungan yang hijau.

Penggunaan elemen-elemen kaca dan elemen logam sangat kontras dengan elemen alam seperti kayu dan pepohonan yang hijau. Tetapi disini sang arsitek berhasil membuat suatu "perbedaan" yang kontras tersebut menjadi sesuatu yang menyatu dan seimbang dengan alam.

\section{Kaitan Yin Yang dengan Tri Hita Karana sebagai Filsafat Lokal}

Jika dikaitkan ajaran Yin Yang dengan filsafat lokal Bali, maka filsafat Yin Yang sangat cocok dengan Filsafat Tri Hita Karana. Tri Hita Karana salah satu ajarannya menjelaskan tentang palemahan yaitu Manusia hidup dalam suatu lingkungan tertentu. Manusia memperoleh bahan keperluan hidup dari lingkungannya. Manusia dengan demikian sangat tergantung kepada lingkungannya. Oleh karena itu manusia harus selalu memperhatikan situasi dan kondisi lingkungannya. Lingkungan harus selalu dijaga dan dipelihara serta tidak dirusak. Lingkungan harus selalu bersih dan rapi. Lingkungan tidak boleh dikotori atau dirusak. Hutan tidak boleh ditebang semuanya, binatang-binatang tidak boleh diburu seenaknya, karena dapat menganggu keseimbangan alam. Lingkungan justu harus dijaga kerapiannya, keserasiannya dan kelestariannya. Lingkungan yang ditata dengan rapi dan bersih akan menciptakan keindahan. Keindahan lingkungan dapat menimbulkan rasa tenang dan tenteram dalam diri manusia.

Pada zaman Majapahit Tri Hita Karana merupakan salah satu dari delapan belas rahasia sukses pemimpin besar Nusantara Gajah Mada pada waktu itu. Gajah Mada memasukkan konsep ajaran Tri Hita Wacana yang harus diikuti oleh para pemimpin Majapahit untuk mewujudkan cita-citanya mempersatukan Nusantara. Konsep Tri Hita Wacana yang dirumuskan oleh Gajah Mada itu,kini lebih dikenal dengan ajaran Tri Hita Karana sebagai sebuah doktrin keselarasan, keserasian, keharmonisan, dan keseimbangan dalam menata ke ajegan HINDU khususnya di Bali (Suhardana, $2008: 77$ )

Tri Hita Karana yang secara etimologi terbentuk dari kata : tri yang berarti tiga, hita berarti kebahagiaan, dan karana yang berarti sebab atau yang menyebabkan, dapat dimaknai sebagai tiga hubungan yang harmonis yang menyebabkan kebahagian. Ketiga hubungan tersebut meliputi:

1. hubungan yang harmonis antara manusia dengan Ida Sang Hyang Widhi Wasa;

2. hubungan yang harmonis antara manusia dengan sesamanya; dan

3. hubungan yang harmonis antara manusia dengan lingkungannya.

Selanjutnya ketiga hubungan yang harmonis itu diyakini akan membawa kebahagiaan dalam kehidupan ini, di mana dalam terminalogi masyarakat HINDU diwujudkan dalam 3 unsur, yaitu: parahyangan, pawongan, dan palemahan.

Parahyangan adalah merupakan kiblat setiap manusia (baca : Hindu) untuk mendekatkan dirinya kepada Sang Pencipta (sangkan paraning dumadi ) yang dikonkretisasikan dalam bentuk tempat suci, pawongan merupakan pengejawantahan dari sebuah pengakuan yang tulus dari manusia itu sendiri, bahwa manusia tak dapat hidup menyendiri tanpa bersama-sama dengan manusia lainnya (sebagai makhluk sosial). Sedangkan palemahan adalah merupakan bentuk kesadaran manusia bahwa manusia hidup dan berkembang di alam, bahkan merupakan bagian dari alam itu sendiri.

Dalam mengimplementasikan konsep Tri Hita Karana yang dimaksud, sangat ditekankan bahwa ketiga unsurnya harus diaplikasikan secara utuh dan terpadu. Unsur parahyangan, pawongan, dan palemahan tidak ada yang menduduki porsi yang istimewa. Dia senantiasa seimbang dalam pemikiran, seimbang dalam ucapan dan seimbang pula dalam segala tindakan. Sebagai konsep keharmonisan HINDU, Tri Hita Karana telah memberikan apresiasi yang luar biasa dari berbagai masyarakat dunia. Unsurparahyangan dalam menjaga keharmonisan dengan Ida Sang Hyang Widhi diwujudkan dalam berbagai bentuk aktivitas yadnyasebagai persembahan 
yang tulus kepada Sang Pencipta. Mulai dari pembangunan tempat suci, pelaksanaan upacara keagamaan, pendalaman ajaran agama, kreativitas berkesenian (tari, tabuh, lukis, pahat, dsb.) untuk kepentingan ritual, kesemuanya itu membuat decak kagum orang-orang di luar sana. Dalam ranah pawongan, masyarakat Hindu dengan konsep manyama-braya, paras-paros sarpanaya, salunglung sabayantaka, dan Tat Twam Asi yang mendasarinya semakin mempertegas eksistensi masyarakat Hindu yang ramah- tamah. Lebih-lebih lagi sesuai ajaran Hindu yang sangat yakin terhadap Hukum Karma Phala membuat kita semakin aman, damai, dan tenteram. Selanjutnya dalam tataran palemahan, perhatian masyarakat Hindu terhadap lingkungannya sudah tidak dapat diragukan lagi. Sebelumnya saya mempunyai sebuah pertanyaan, "Adakah agama di dunia ini mempunyai hari raya yang terkait dengan lingkungan ?" Jawabnya adalah 'tidak' kecuali Hindu. Karena apabila agama lain ada upacara untuk itu, berarti ia memperkuat kultus berhala, sementara ia sangat alergi dengan hal-hal berhala. Bagaimana dengan Hindu ? Hindu bukan agama berhala, walau ada hari raya Tumpek Pengarah untuk tumbuh-tumbuhan, Tumpek Kandang untuk segala macam ternak, Tumpek Landep untuk segala macam perabotan (senjata) sebagai sarana-prasarana mencari kehidupan, Nyepi untuk keharmonisan jagat raya, dan lain sebagainya. Karena substansi dari hari raya itu adalah persembahan yang tulus kehadapan Ida Sang Hyang Widhi sebagai rasa syukur atas segala kemudahan yang dianugrahkan-Nya melalui media yang ada di alam semesta ini, dengan diiringi oleh sebuah permohonan semoga di anugerahkan kelestarian dan kemakmuran yang berkeseimbangan dan berkelanjutan.

Di Bali, salah satu implementasi Tri Hita Karana adalah sistem irigasi subak. Subak adalah organisasi kemasyarakatan yang khusus mengatur sistem pengairan sawah yang digunakan dalam cocok tanam padi di Bali. Subak ini biasanya memiliki pura yang dinamakan Pura Uluncarik, atau Pura Bedugul, yang khusus dibangun oleh para petani dan diperuntukkan bagi dewi kemakmuran dan kesuburan Dewi Sri. Sistem pengairan ini diatur oleh seorang pemuka adat yang juga adalah seorang petani di Bali.

Revolusi hijau telah menyebabkan perubahan pada sistem irigasi ini, dengan adanya varietas padi yang baru dan metode yang baru, para petani harus menanam padi sesering mungkin, dengan mengabaikan kebutuhan petani lainnya. Ini sangatlah berbeda dengan sistem Subak, di mana kebutuhan seluruh petani lebih diutamakan. Metode yang baru pada revolusi hijau menghasilkan pada awalnya hasil yang melimpah, tetapi kemudian diikuti dengan kendalakendala seperti kekurangan air, hama dan polusi akibat pestisida baik di tanah maupun di air. Akhirnya ditemukan bahwa sistem pengairan sawah secara tradisional sangatlah efektif untuk menanggulangi kendala ini.

Subak telah dipelajari oleh Clifford Geertz, sedangkan J. Stephen Lansing telah menarik perhatian umum tentang pentingnya sistem irigasi tradisional. la mempelajari pura-pura di Bali, terutama yang diperuntukkan bagi pertanian, yang biasa dilupakan oleh orang asing. Pada tahun 1987 Lansing bekerja sama dengan petani-petani Bali untuk mengembangkan model komputer sistem irigasi Subak. Dengan itu ia membuktikan keefektifan Subak serta pentingnya sistem ini.

\section{Simpulan dan Saran}

Yin Yang dengan 5 elemen yang meliputinya, yaitu: kayu, tanah, logam, api dan air adalah dua prinsip induk dari seluruh kenyataan. Yin itu bersifat pasif, prinsip ketenangan, surga, bulan, air dan perempuan, simbol untuk kematian dan untuk yang dingin. Yang itu prinsip aktif, prinsip gerak, bumi, matahari, api, dan laki - laki, simbol untuk hidup dan untuk yang panas. Segala sesuatu dalam kenyataan kita merupakan sintesis harmonis dari derajat Yin tertentu dan derajat Yang tertentu . Kedua, ajaran Taoisme tentang Yin-Yang juga dapat memberi kearifan. Yang biasanya digambarkan sebagai agresif, maskulin, kompetitif, dan rasional. Sementara Yin dilukiskan konservatif, intuitif, kooperatif, feminin, dan responsif. Yin-Yang harus berjalan secara sejajar dan seimbang, sehingga keharmonisan antara makrokosmos dan mikrokosmos terwujud. Kenyataan kita lebih suka berpikir rasional, linear, mekanistik, dan materialistik perlu diseimbangkan dengan pengetahuan yang intuitif, non-linear, dan koordinatif, sebagai perwujudan Yin (kearifan ekologis). Keyakinan terhadap Yin Yang meski harus terus dipertahankan sebab tuntutan terhadap keberadaan manusia akhir-akhir ini sering merasa terancam dengan perilaku yang dilakukannya sendiri. Semangat Yin Yang adalah back to naturesebab manusia adalah bagian dai penyeimbang alam itu sendiri. 
Manusia merupakan sebuah mikrokosmos dalam hubungannya dengan makrokosmos atau alam semesta. Sebagai bagian pelengkap yang penting, manusia seharusnya tunduk pada hukum-hukum kosmos yang sama. Keseluruhan susunan alam semesta terbentuk dari keseimbangan yang sempurna antara kekuatan Yang dan Yin. Kejenuhan orang terhadap berbagai macam terapan kimiawi dan bebagai macam rekayasa genetika membuat prinsip Yin Yang yang terus berinteraksi dengan alam semakin mengukuhkan dirinya sebagai hal yang patut didalami, dikembangkan dan implementasikan oleh manusia.

\section{Daftar Pustaka}

Dian, 1996. Logika Feng Shui. Seni Mencapai Hidup Harmonis \& Bahagia Dalam Keberuntungan Bumi (Buku Satu). Jakarta : Penerbit PT Elex Media Komputindo Kelompok Gramedia. Mulia

Hartono, Chris. 1974. Ke-Tionghoaan dan Kekristenan. Jakarta : Penerbit BPK Gunung Tarsito.

Hidayat, Z.M.1993. Masyarakat dan Kebudayaan Cina di Indonesia. Bandung : Penerbit

Koentjaraningrat, 2002. Manusia Dan Kebudayaan Di Indonesia. Jakarta : Penerbit : Djambatan .

Lasiyo (dkk). 1995. Konfusianisme Di Indonesia. Pergulatan Mencari Jati Diri. Yogyakarta : Penerbit INTERFIDEI.

Naveront, Jhon K.1997. Jaringan Masyarakat Cina. Jakarta : PT Golden terayon Press.

Seeger, Elizabeth. 1951. Sedjarah Tiongkok Selajang Pandang. Terjemahan Ong Pok Kiat \& Sudarno. Djakarta : J.B. Wolters-Groningen

Skinner, Stephen.. 2003. Feng Shui. IImu Tata letak Tanah Dan Kehidupan Cina Kuno. Semarang : Dahara Prize.

Tan, Mely G.1981. Golongan Etnis Tionghoa di Indonesia. Suatu Masalah Pembinaan Kesatuan Bangsa . Jakarta : PT Gramedia. 